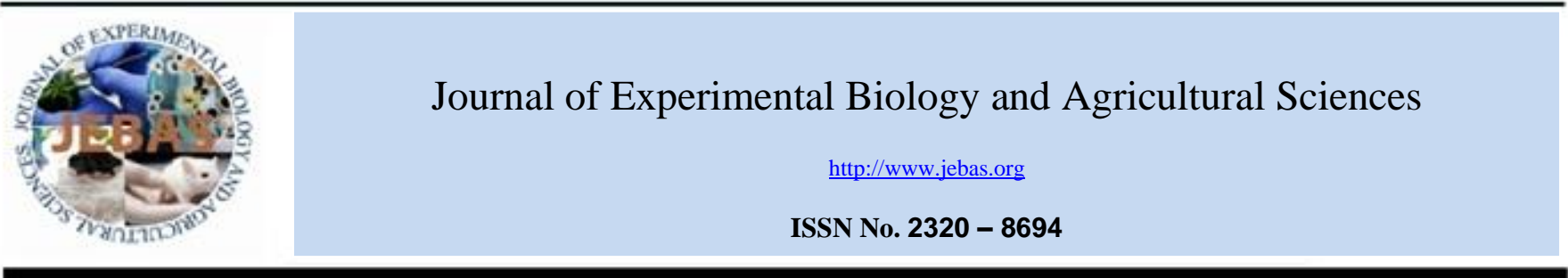

\title{
EVALUATION OF ANTIOXIDANT AND ANTIFUNGAL PROPERTIES OF PALU SHALLOT (Allium ascalonicum L VAR. Aggregatum)
}

\section{Muhammad Sulaiman Zubair*, Agustinus Widodo, Mira Fatmasari, Febriana De'e, Arsa Wahyu Nugrahani}

Department of Pharmacy, Faculty of Mathematics and Natural Sciences, Tadulako University, Kampus Bumi Tadulako, 94118 , Palu, Indonesia

Received - December 25, 2020; Revision - March 29, 2021; Accepted - April 29, 2021

Available Online - September 08, 2021

DOI: http://dx.doi.org/10.18006/2021.9(Spl-2-ICOPMES_2020).S215.S221

\section{KEYWORDS \\ Total phenolics \\ Total flavonoids \\ Quercetin \\ DPPH \\ Candida albicans \\ Allium ascalonicum}

\begin{abstract}
Shallot is one of the typical plants at Palu, Central Sulawesi, Indonesia, famous by local people as fried Shallot. It is used as a cooking spice and traditional medicine for treating various diseases. This study was carried out to assess the phytochemical constituent including total phenolics, total flavonoids, and quercetin content of the Palu shallot (Allium ascalonicum L var. aggregatum), and to determine the antifungal and antioxidant properties of this plant ethanolic extract. Total phenolics/ flavonoids and quercetin concentration were determined by spectrophotometry UV-Vis and Reverse Phase - HighPerformance Liquid Chromatography (RP-HPLC) methods. Antifungal activity and antioxidant capacity of the ethanolic extract was assayed by using diffusion agar and 2,2-diphenyl-1-picrylhydrazyl (DPPH) methods. Results of the study revealed that the total flavonoids content of the ethanolic extract was $0.3634 \pm 0.018 \mathrm{mg}$ QE/100 mg while total phenolics content was $0.4834 \pm 0.003 \mathrm{mg} \mathrm{GAE} / 100 \mathrm{mg}$. Meanwhile, the quercetin content was $65.46 \pm 0.0002 \mathrm{mg} / \mathrm{kg}$. Further, ethanolic extract of Palu shallot also showed the radical scavenging activity with $\mathrm{IC}_{50}$ of $0.1398 \mathrm{mg} / \mathrm{mL}$ and growth inhibition on Candida albicans with inhibitory zone diameter range from 7.57 to $16.51 \mathrm{~mm}$. This study confirms the high quality of Palu shallot as it has high total flavonoids, represented by the high quercetin concentration, and it is proposed to be a source for an antioxidant and antifungal medicinal herb.
\end{abstract}

* Corresponding author

E-mail: sulaiman_zubair80@yahoo.co.id (Muhammad Sulaiman Zubair)

Peer review under responsibility of Journal of Experimental Biology and Agricultural Sciences.

Production and Hosting by Horizon Publisher India [HPI] (http://www.horizonpublisherindia.in/).

All rights reserved.
All the articles published by Journal of Experimental Biology and Agricultural Sciences are licensed under a Creative Commons Attribution-NonCommercial 4.0 International License Based on a work at www.jebas.org.

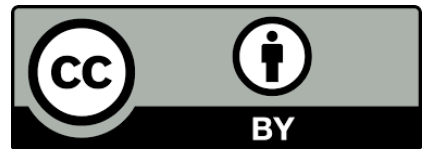




\section{Introduction}

Shallot (Allium ascalonicum Linn.), belonging to the family Liliaceae, is the most widely consumed vegetable in the world and widely used as a food, spice and folk medicine. The bioactive compounds and pharmacological activities such as antimicrobial (Kyung, 2012), antiviruses (Mohamed, 2010), antioxidant (Raeisi et al., 2016), antifungal (Moghim et al., 2014), haematological effects (Owoyele et al., 2004), anticancer and anti-inflammatory (Mohammadi-Motlagh et al., 2011) have been well studied so far. Meanwhile, ascalonicoside A1/A2 and ascalonicoside B (Fattorusso et al., 2002), four sulfur-containing compounds (Ogra et al., 2005), and ascalin (Wang \& Ng, 2002) had also been reported from bulbs of Shallot. Besides, the flavonoid fractions of Shallot contained high amounts of free quercetin, glycoside form such as quercetin 4'-glucoside and quercetin 7-glucoside, and isorhamnetin (Fattorusso et al., 2002).

In Central Sulawesi with a dry climate, there is a type of shallot that can grow and produce well. This type of local shallot is known as Palu shallot and has been processed into a ready-to-eat product commonly called Palu fried shallot (Figure 1). Palu shallot has advantages like a dense texture, a savoury taste and an unchanging aroma even though it is stored for a long time. Besides, Palu shallot has many nutrients, including protein, fat, carbohydrates, vitamin A, vitamin E, and a small number of vitamins B (thiamine, riboflavin, niacin, pantothenic acid, and pyridoxine) (Sulfina, 2020).

Quercetin was found as one of the primary compounds in some varieties of Shallot (Sittisart et al., 2017). The antioxidant capacity is always associated with the properties of quercetin because of its ability to capture free radicals and reactive oxygen such as superoxide anions and hydroxyl radicals (Zhang et al., 2011). In addition, flavonoids compounds can also disrupt the cell proteins and shrink the cell walls causing apoptosis induction in several candida species (Seleem et al., 2017).

Considering the more advantage of consuming Palu shallot as daily food and the wide cultivation of this plant in Palu and its surrounding area, there is a need for extract material standardization based on phytochemical characteristics and pharmacological activity information. Therefore, this study aims to determine the total phenolics/flavonoids of extract and continuing by determination of its quercetin concentration. The antioxidant and antifungal activities of ethanol extract of bulbs of Palu shallot were also discussed.

\section{Materials and methods}

\subsection{Materials}

Fresh bulbs of Palu Shallot (A. Ascalonicum var. aggregatum) were collected from Soulove village, Sigi Regency $( \pm 25 \mathrm{~km}$ from Palu City, Central Sulawesi, Indonesia). The plant identification was done in the Plant Biosystematical Laboratory, Department of Biology, Science Faculty, Tadulako University, Palu, Indonesia where a voucher specimen was deposited. Other commonly used materials are gallic acid, quercetin ( $\geq 95 \%$ purity), 1,1-difenil-2pikrilhidrazil (DPPH), potato dextrose agar (PDA) medium, ethanol $96 \%$, nystatin $0.1 \%, \mathrm{NaCl} 0.9 \%$ physiologic solution, sodium nitrite, sodium hydroxide, sodium carbonate, ascorbic acid sodium carbonate, aluminium chloride, Folin-Ciocalteau 50\% reagent, Dimetil Sulphoxide (DMSO), methanol, methanol proHPLC, water pro-HPLC, and aqua dest. All chemicals were purchased from Sigma Aldrich.

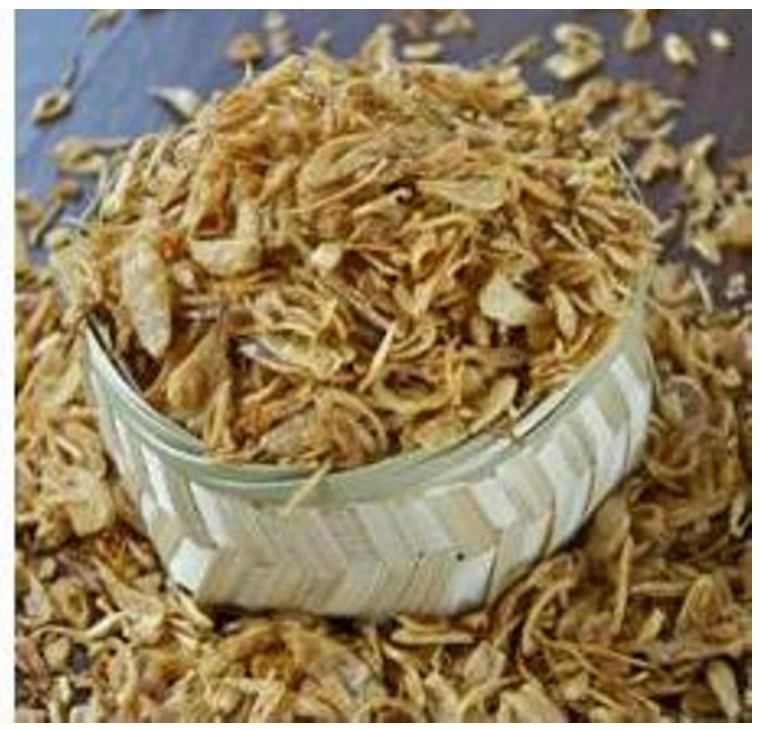

Figure 1 Palu shallot (left), ready to eat product of Palu fried shallot (right)

Journal of Experimental Biology and Agricultural Sciences http://www.jebas.org 


\subsection{Extraction}

Bulbs of Palu shallot were cleaned of skin, epidermis and leaves and then chop them into smaller pieces. It was dried at room temperature protected from direct sunlight. Around $1 \mathrm{~kg}$ of dried bulbs was weighed and then extracted by maceration using $2.5 \mathrm{~L}$ of $96 \%$ ethanol. The macerator was then tightly closed and stored in a place protected from sunlight for $3 \times 24$ hours and concentrated using a rotary evaporator until obtained the viscous extract (64.67 g).

\subsection{Total Flavonoids Determination}

The measurement of total flavonoids were conducted by the aluminium chloride colorimetric method as suggested by Karagiorgou et al. (2016) and Sulastri et al. (2018,). About $10 \mathrm{mg}$ of sample was dissolved in $10 \mathrm{~mL}$ ethanol (p.a) and then diluted to $100 \mu \mathrm{g} / \mathrm{mL}$. Meanwhile, quercetin as standard was also prepared by dissolving $10 \mathrm{mg}$ in $10 \mathrm{~mL}$ ethanol p.a $(1000 \mu \mathrm{g} / \mathrm{mL})$ and then diluted to 5, 10, 20 and $40 \mu \mathrm{g} / \mathrm{mL}$. Sample and each concentration of standard solutions (1:1) were mixed with $0.2 \mathrm{~mL} 1 \mathrm{M}$ potassium acetate, $0.2 \mathrm{~mL} 10 \%$ aluminium chloride, $3 \mathrm{~mL} \mathrm{96 \%} \mathrm{ethanol,} \mathrm{and}$ $5.6 \mathrm{~mL}$ distilled water. Then, the mixture was incubated at room temperature for 10 minutes. The absorbance was measured by using spectrophotometer UV-Vis Cecil CE7410 at $447 \mathrm{~nm}$, along with a blank solution. Total flavonoid was calculated and resulted in milligrams of quercetin equivalent (QE) per $100 \mathrm{mg}$ extract. The experiment was performed in triplicates.

\subsection{Total Phenolics Determination}

The measurement of total phenolics was conducted by using Folin-Ciocalteu method as described by Hossain \& Rahman (2011) and Sulastri et al. (2018). For this, $10 \mathrm{mg}$ gallic acid as standard was dissolved in $10 \mathrm{~mL}$ ethanol p.a $(1000 \mu \mathrm{g} / \mathrm{mL})$. This solution was diluted to obtain standard solutions with the concentration series of 5, 10, 20 and $40 \mu \mathrm{g} / \mathrm{mL}$. Similarly, $10 \mathrm{mg}$ plant sample was also dissolved in $10 \mathrm{~mL}$ ethanol p.a. About 0.5 $\mathrm{mL}$ standards and sample solutions were mixed with 50\% FolinCiocalteu and distilled water (1:1) and added $2 \mathrm{~mL}$ of sodium carbonate $(7.5 \%$, w/v) after incubation for $5 \mathrm{~min}$. The mixture was then shaken and incubated for $15 \mathrm{~min}$ at room temperature. The absorbance of standard and sample solutions were measured by using spectrophotometer UV-Vis Cecil CE7410 at $755 \mathrm{~nm}$. Total phenolic content was calculated and resulted in milligrams of gallic acid equivalents (GAE) per $100 \mathrm{mg}$ extract. The experiment was performed triplicates.

\subsection{Quercetin Concentration Determination}

The concentration of quercetin on ethanol extract was determined by RP-HPLC. $20 \mathrm{mg}$ dried ethanol extract was dissolved in $10 \mathrm{~mL}$ methanol and sonicated for 15 minutes. Similarly, $10 \mathrm{mg}$ quercetin as standard was dissolved in $10 \mathrm{ml}$ methanol and then diluted to obtain the concentration series of 1.2, 2.4, 4.8, 9.6 and $19.2 \mu \mathrm{g} / \mathrm{mL}$. Samples and standard solutions were filtered through a $0.45 \mu \mathrm{m}$ millipore filter and then injected into the column (C18 size 250 $\mathrm{mm} \times 4.6 \mathrm{~mm}$ ) on HPLC Cecil CE4201 with UV visible detector. Methanol: water $(90: 10, \mathrm{v} / \mathrm{v})$ with parameters: injection volume 20 $\mu \mathrm{L}$, the flow rate of $1 \mathrm{~mL} / \mathrm{min}$, and detection wavelength at $370 \mathrm{~nm}$ was used to obtain the optimum efficiency of separation. Quercetin concentration was calculated by linear regression analysis using SPSS 17.0 (SPSS. Inc, Chicago IL, USA).

\subsection{Antioxidant Activity Determination}

The antioxidant activity of Palu shallot ethanol extracts was determined by using DPPH radical method (Karimi \& Moradi, 2015). About $3 \mathrm{~mL}$ of both $0.1 \mathrm{mM}$ DPPH solution and ethanol solutions of extracts (concentration series of $50-150 \mu \mathrm{g} / \mathrm{mL}$ ) were mixed and incubated for $30 \mathrm{~min}$ at the darkroom. The decreasing absorbance of the mixture was monitored at $515 \mathrm{~nm}$. Blank sample and vitamin $\mathrm{C}$ (concentration series of $1,2,4,6$, and $8 \mu \mathrm{g} / \mathrm{mL}$ ) as positive control were also prepared and measured at the same wavelength. The experiment was carried out in triplicate. The calculation of the percentage of inhibition was done by the following formula:

\%inhibition=

$\left(\frac{\text { Absorbance of blank solution -Absorbance of sample solution }}{\text { Absorbance of blank solution }}\right) \times 100 \%$

Meanwhile, the $50 \%$ inhibitory concentration $\left(\mathrm{IC}_{50}\right)$ was calculated by probit analysis correlating the extract concentrations against their inhibition percentage.

\subsection{Determination of antifungal activity}

\subsubsection{Test microorganisms}

Candida albicans, isolated from candidiasis patient at Palu Health Laboratory Office, were cultured on potato dextrose agar. Incubation was performed at $37^{\circ} \mathrm{C}$ for $18-24 \mathrm{~h}$.

\subsubsection{Disc diffusion assay}

The antifungal activity of ethanol extracts of Palu shallot was performed by the well-diffusion method (NCCLS, 2012). C. albicans fungi were cultured overnight at $37^{\circ} \mathrm{C}$ on Potato Dextrose broth. Inoculums consisting of $0.5 \mathrm{McFarland}$ was prepared in physiologic saline. Fungi inoculums in potato dextrose agar medium $(2000 \mu \mathrm{L})$ was poured in Petri dishes with a Potato Dextrose Agar solid medium (1000 uL) as basis layer. The sample was prepared by dissolving $1 \mathrm{~g}$ extract on $1 \mathrm{~mL}$ DMSO (1000 $\mathrm{mg} / \mathrm{mL}$ ) and then dilute to 250,500 and $750 \mathrm{mg} / \mathrm{mL}$. Sterile wells (6 mm diameter) were deposited on medium and impregnated with $50 \mu \mathrm{L}$ of extract solutions. The plates were inverted and incubated 
for $3 \times 24 \mathrm{~h}$ at $37^{\circ} \mathrm{C}$. The negative control was performed with discs containing $50 \mu \mathrm{L}$ of DMSO and the positive control was nystatin $1 \mathrm{mg} / \mathrm{mL}$. Each experiment was performed in triplicate. The diameters of the clear zone of growth inhibition around each disc were measured and recorded. The scale of measurement (disc diameter included) is as follow: $<12 \mathrm{~mm}$ is no inhibitory activity, $<20-12 \mathrm{~mm}$ is moderate inhibitory activity; and $\geq 20 \mathrm{~mm}$ is strong inhibitory activity (Espina et al., 2011).

\section{Results and Discussion}

In the Province of Central Sulawesi, particularly in Soulove village, Sigi Regency, there is a local commodity of superior shallots, which is already well known as a source of typical fried onion ingredients with more distinctive taste compared to other shallots in the country. It is known as local Palu shallot or better known as Palu fried shallot. Palu shallot varieties in Soulove village are cultivated traditionally by farmers. Shallot farming has been started for decades, especially around the Soulove village where shallot can adapt well to lowland areas with dry climates (Yusuf et al., 2016).

In this study, phytochemical analysis was performed to measure the amount of total phenolics/flavonoids and quercetin concentration on an ethanol extract of Palu shallot bulbs. The results can be seen in Table 1 . Total phenolics was calculated according to equation from gallic acid graph with $\mathrm{y}=0.016 \mathrm{x}+$ $0.048\left(R^{2}=0.998\right)$. The total phenolic, expressed as gallic acid equivalents (GA), was found of $0.4834 \pm 0.003 \mathrm{mg} \mathrm{GA} / 100 \mathrm{mg}$ of dry extract. Meanwhile, the total flavonoid, expressed as quercetin equivalents $(\mathrm{QE})$, was $0.3634 \pm 0.018 \mathrm{mg} / 100 \mathrm{mg}$ of dry extract obtained from the equation of quercetin graph, $\quad \mathrm{y}=0.011 \mathrm{x}+$ $0.024\left(\mathrm{R}^{2}=0.996\right)$. A. ascalonicum was reported to contain more total flavonoids than other types of onion varieties (Fattorusso et al., 2002). The total flavonoid of ethanol extract of onion (Allium cepa) and garlic (A. sativum) was reported in the range of $0.015-$ $0.02 \mathrm{mg} \mathrm{CE} / 100 \mathrm{mg}$ and the total phenolic of ethanol extract of garlic (A. sativum) was $0.6 \mathrm{mg}$ GAE/ $100 \mathrm{mg}$ (Priecina \& Karlina, 2013).

Table 1 Phytochemical analysis of ethanol extract of Palu Shallot

\begin{tabular}{|cc|}
\hline Analysis & Ethanol extract \\
\hline $\begin{array}{c}\text { Total phenolics } \\
(\mathrm{mg} / 100 \mathrm{mg}) \text { in GAE }\end{array}$ & $0.4834 \pm 0.003$ \\
\hline $\begin{array}{c}\text { Total flavonoids } \\
(\mathrm{mg} / 100 \mathrm{mg}) \text { in } \mathrm{QE}\end{array}$ & $0.3634 \pm 0.018$ \\
\hline $\begin{array}{c}\text { Quercetin concentration } \\
(\mathrm{mg} / \mathrm{kg})\end{array}$ & $65.46 \pm 0,0002$ \\
\hline
\end{tabular}

Shallot was characterized by the presence of flavonoid compounds of quercetin. Therefore, quercetin concentration in ethanol extract of Palu shallot bulbs was conducted by using RP-HPLC. The quercetin concentration on the extract was quantified based on the obtained quercetin standard calibration curve, $y=9.368 \mathrm{x}+11.82$ $\left(\mathrm{R}^{2}=0.993\right)$. HPLC chromatogram showed that a peak for quercetin on the ethanol extract can be comparable with the peak of quercetin standard with the retention time (RT) of 2.53 (Figure 2). Using calibration curve plotting between concentration and peak area, Palu shallot was found to contain quercetin of $65.46 \pm 0.0002 \mathrm{mg} / \mathrm{kg}$.

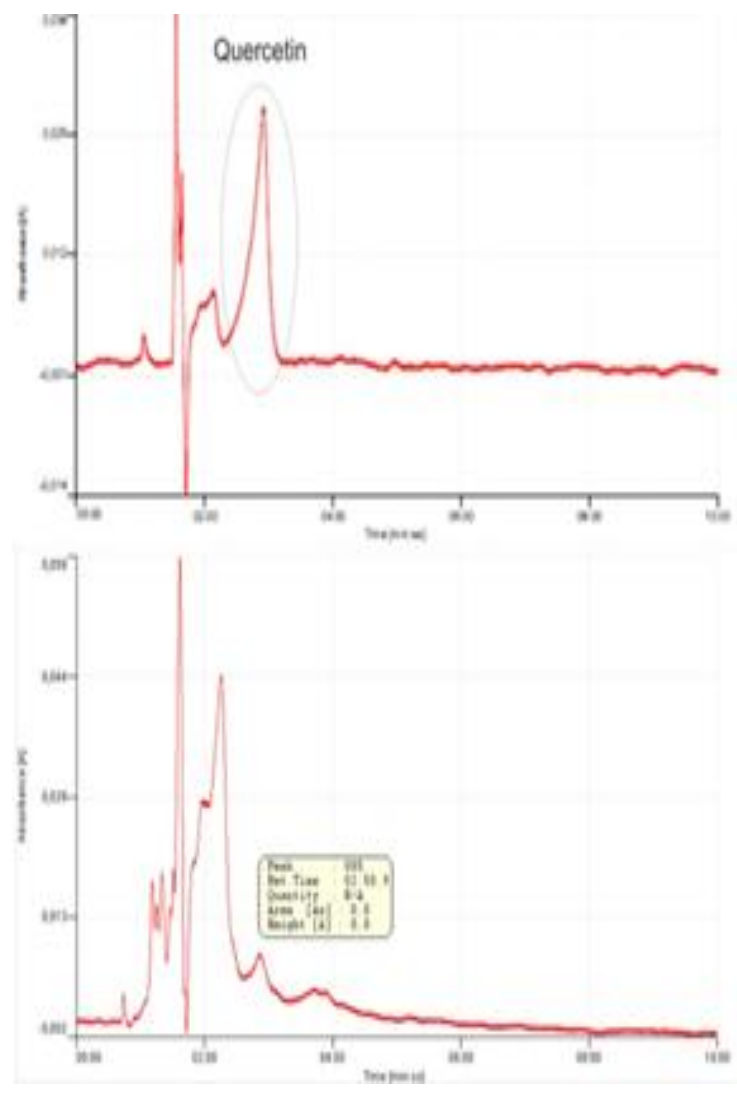

Figure 2 HPLC chromatogram of ethanol extract of Palu shallot bulbs.

This is the first report of the concentration of quercetin on Palu shallot. Pobłocka-olech et al. (2016) had studied the quercetin level on Onion (A. cepa) and Shallot (A. ascalonicum) from Polland and found that the edible part of onion only contains 11,17 , and 24 $\mathrm{mg} / \mathrm{kg}$ for gold onion type red baron, amstrong, and exhibition, respectively and for shallot with types of ambition and matador did not contain quercetin (Pobłocka-olech et al., 2016). The quercetin level of red onion was reported as $30.0 \pm 0.00 \mathrm{mg} / \mathrm{kg}$ (Kwak et al., 2017). This study supports the high quality of Palu Shallot according to quercetin content on ethanol extract. 
Further study was continued to assay the antioxidant and antifungal activities. The DPPH antioxidant activity test of ethanol extract showed the percentage of inhibition of $33.50 \%, 44.27 \%$, and $54.45 \%$ at concentration series of 100,125 , and $150 \mu \mathrm{g} / \mathrm{mL}$, respectively (Figure 3). Moreover, it also inhibited the growth of C. albicans at concentrations of $250,500,750$, and $1000 \mathrm{mg} / \mathrm{mL}$ with the inhibitory zone diameter of $7.57 \mathrm{~mm}, 9.88 \mathrm{~mm}, 14.39$ $\mathrm{mm}$, and $16.51 \mathrm{~mm}$, respectively (Figure 4). Acheampong and colleagues (2016) have reported that total phenolics have a correlation with the antioxidant activity of several vegetables, including A. ascalonicum. The higher phenolic content will affect the higher antioxidant capacity. The methanol extract of $A$. ascalonicum was reported to contain a total phenolic of $0.124 \mathrm{mg}$ TAE/DW, and DPPH scavenging activity was $2.2708 \mathrm{mg} / \mathrm{mL}$ (Acheampong et al., 2016). Comparing this study, the ethanol extract of Palu shallot also showed high antioxidant activity where the $\mathrm{IC}_{50}$ was $0.1398 \mathrm{mg} / \mathrm{mL}$ (Table 2).

Table $2 \mathrm{IC}_{50}$ of ethanol extract of Palu Shallot

\begin{tabular}{|cc|}
\hline Sample & $\mathrm{IC}_{50}(\mathrm{mg} / \mathrm{mL})$ \\
\hline Ethanol extract & 0.1398 \\
\hline Vitamin C & 0.0037 \\
\hline
\end{tabular}

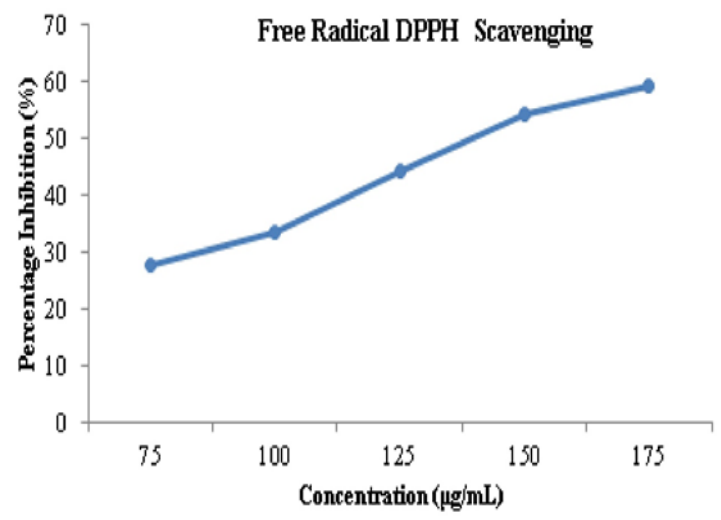

Figure 3 Antioxidant activity of ethanol extract of Palu shallot

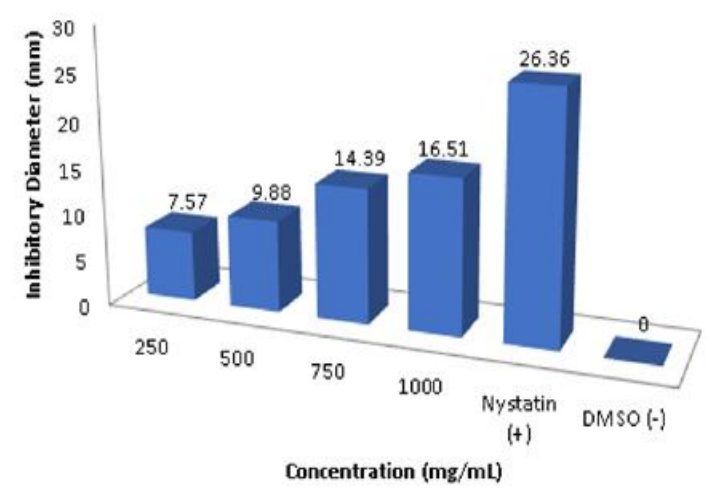

Figure 4 Inhibitory zone diameter ( $\mathrm{mm}$ ) of ethanol extract of Palu shallot against $C$. albicans
Shallot was reported to have the highest antifungal activity against the $C$. albicans. The minimum fungicidal concentration (MFC) of its ethanol extract on C. albicans was $20 \mathrm{mg} / \mathrm{ml}$ (Moghim et al., 2014). It is also found that shallot has more effect on saphrophyte than C. albicans (Mahmoudabadi \& Naser, 2009). In this research, Palu shallot showed antifungal inhibition on all concentrations used with the range of inhibitory zone diameter range from 7.57 to $16.51 \mathrm{~mm}$. The result is following the previous reports regarding the antifungal activity of Shallot. Wang \& Ng (2002) reported ascalin as the main compound that responsible for the inhibition of mycelial growth in several fungi.

This study supports the application of Palu shallot as a potential natural antioxidant and antifungal agent based on total phenolics, total flavonoids, and quercetin content. Although it has been used as a food flavor in daily seasoning, it has also been widely applied as a raw material in the food industry (snacks production and cooking seasoning) (Sun et al., 2019). It is suggested to develop Palu shallot as raw material for drug formulation or as functional food products.

\section{Conclusion}

Palu shallot was analyzed for total phenolics, total flavonoids, and quercetin content with the amount of $0.4834 \pm 0.003 \mathrm{mg} / 100 \mathrm{mg}$ GAE, $0.3634 \pm 0.018 \mathrm{mg} / 100 \mathrm{mg} \mathrm{QE}$, and $65.46 \pm 0.0002 \mathrm{mg} / \mathrm{kg}$, respectively. Examination of DPPH scavenging activity and agar diffusion methods showed antioxidant activity with the $\mathrm{IC}_{50}$ of $0.1398 \mathrm{mg} / \mathrm{mL}$ and growth inhibition of $C$. albicans at all concentrations. This study supports the potency of local Palu shallot to be an antioxidant and antifungal medicinal herb.

\section{Acknowledgement}

The authors are grateful to the Chairman, Department of Pharmacy, Tadulako University, for financial support via Lektor Research Grant (No. 5873/UN28.1.28/KP/2018) and laboratory facilities used in this study as well.

\section{Conflict of Interest}

The authors declare no conflict of interest

\section{References}

Acheampong A, Badu M, Agyemang AY (2016) Comparative Total Phenolics and Antioxidant Activities of Xanthosoma colocasia, Solanum torvum and Allium ascalonicum L. International Journal of Chemical and Biomolecular Science 2(4): 73-79.

Espina L, Somolinos M, Lorán S, Conchello P, García D, Pagán R (2011) Chemical composition of commercial citrus fruit essential

Journal of Experimental Biology and Agricultural Sciences http://www.jebas.org 
oils and evaluation of their antimicrobial activity acting alone or in combined processes. Food Control 22(6): 896-902.

Fattorusso E, Lorizzi M, Lanzotti V, Taglialatela-Scafati O (2002) Chemical composition of Shallot (Allium ascalonicum Hort). Journal of Agricultural and Food Chemistry 50(20): 5686-5890.

Hossain MA, Rahman SMM (2011) Total phenolics, flavonoids and antioxidant activity of tropical fruit pineapple. Food Research International 44: 672-676.

Karagiorgou I, Grigorakis S, Lalas S, Makris DP (2016) Polyphenolic burden and in vitro antioxidant properties of Moringa oleifera root extracts. Journal of Herbmed Pharmacology 5(1): $33-$ 38 .

Karimi A, Moradi MT (2015) Total phenolic compounds and in vitro antioxidant potential of crude methanol extract and the correspond fractions of Quercus brantii L. acorn, Journal of Herbmed Pharmacology 4(1): 35-39.

Kwak JH, Seo JM, Kim NH, Arasu MV, Kim S, Yoon MK, et al (2017) Variation of quercetin glycoside derivatives in three onion (Allium cepa L.) varieties. Saudi Journal of Biological Sciences 24 1387-1391.

Kyung KH (2012) Antimicrobial properties of Allium species. Current Opinion in Biotechnology 23(2): 142-147.

Mahmoudabadi AZ, Naser MKG (2009) Antifungal activity of Shallot, Allium ascalonicum Linn (Liliaceae) in vitro. Journal of Medicinal Plants Research 3(5): 450-453.

Moghim H, Taghipoor S, Shahinfard N, Kheiri S, Heydari Z, Rafieian S (2014) Antifungal effects of Allium ascalonicum, Marticaria chamomilla and Stachys lavandulifolia extracts on Candida albicans. Journal of Herbmed Pharmacology 3(1): 9-14.

Mohamed EF (2010) Antiviral properties of garlic cloves juice compared with onion bulbs juice against potato virus Y (PVY). Journal of American Science 6: 302-310.

Mohammadi-Motlagh HR, Mostafaie A, Mansouri K (2011) Anticancer and anti-inflammatory activities of shallot (Allium ascalonicum) extract. Archives of Medical Science 7(1): 38-44.

NCCLS (2012) Performance standards for antimicrobial disk susceptibility tests; approved standard-eleventh edition, CLSI document M02 A11 Wayne, PA. Clinical and Laboratory Standards Institute.

Ogra Y, Ishiwata K, Iwashita Y, Suzuki KT (2005) Simultaneous speciation of selenium and sulfur species in selenized odorless garlic (Allium sativum L. Shiro) and Shallot (Allium ascalonicum) by HPLC inductively coupled plasma-(octopole reaction system)mass spectrometry and electrospray ionization-tandem mass spectrometry. Journal of Chromatography A 1093: 118-125.

Owoyele BV, Alabi OT, Adebayo JO, Soladoye AO, Abioye AI, Jimoh SA (2004) Haematological evaluation of ethanolic extract of Allium ascalonicum in male albino rats. Fitoterapia 75: 322-326.

Pobłocka-olech L, Głód D, Żebrowska ME, Sznitowska M, Krauze Baranowska M (2016) TLC determination of flavonoids from different cultivars of Allium cepa and Allium ascalonicum. Acta Pharmaceutica 66: 543-554.

Priecina L, Karlina D (2013) Total Polyphenol, Flavonoid Content and Antiradical Activity of Celery, Dill, Parsley, Onion and Garlic Dried in Conventive and Microwave-Vacuum Dryers. International Conference on Nutrition and Food Science 53: 107-112.

Raeisi S, Sharifi-Rad M, Quek SY, Shabanpour B, Sharifi-Rad J (2016) Evaluation of antioxidant and antimicrobial effects of Shallot (Allium ascalonicum L.) fruit and ajwain (Trachyspermum ammi (L.) Sprague) seed extracts in semi-fried coated rainbow trout (Oncorhynchus mykiss) fillets for shelf-life extension. LWT Food Science Technology 65: 112-121.

Seleem D, Pardi V, Murata RM (2017) Review of flavonoids: A diverse group of natural compounds with anti-Candida albicans activity in vitro. Archives of Oral Biology 76: 76-83.

Sittisart P, Yossan S, Prasertsan P (2017) Antifungal property of chili, shallot and garlic extracts against pathogenic fungi, Phomopsis spp., isolated from infected leaves of para rubber (Hevea brasiliensis Muell. Arg.). Agriculture and Natural Resources 51: 485-491.

Sulastri E, Zubair MS, Anas NI, Abidin S, Hardani R, Yulianti R, et al (2018) Total Phenolic, Total Flavonoid, Quercetin Content and Antioxidant Activity of Standardized Extract of Moringa oleifera Leaf from Regions with Different Elevation. Pharmacognosy J 10(6S): s104-s108.

Sulfina R (2020) Respons in growth and yield of the local Palu shallot (Allium ascalonicum L.Var. Aggregatum) to the direction and building form of the planting beds. International Journal of Advanced Science and Technology 29(6): 1839-1848.

Sun W, Shahrajabian MH, Cheng Q (2019) The insight and survey on medicinal properties and nutritive components of Shallot. Journal of Medicinal Plants Research 13(18): 452-457.

Wang HX, Ng TB (2002) Ascalin, a new antifungal peptide with human immunodeficiency virus type 1 reverse transcriptaseinhibiting activity from shallot bulbs. Peptides 23: 1025-1029. 
Yusuf R, Syakur A, Budiatno, Mas'ud Hidayati (2016) Application Z Zhang M, Swarts SG, Yin L, Liu C, Tian Y, Cao Y, et al (2011) of some types of seaweeds on the growth and yield of shallot Antioxidant properties of quercetin. Advances in Experimental (Allium ascalonicum L.). Agroland: The Agricultural Sciences Medicine and Biology 701: 283-289.

Journal 3(2): 81- 86.

Journal of Experimental Biology and Agricultural Sciences http://www.jebas.org 